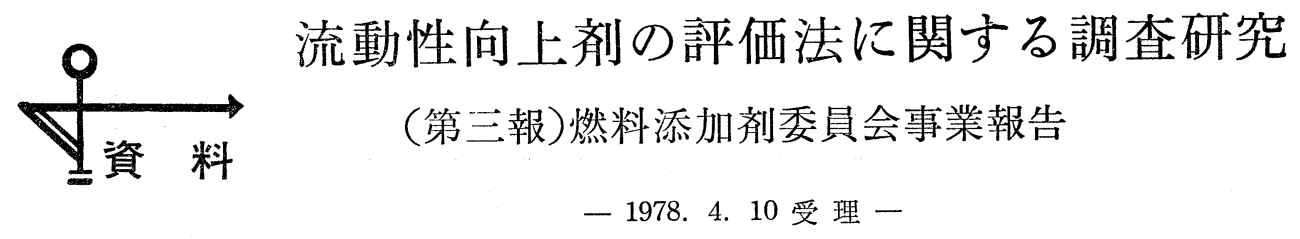

（社）燃料協会 燃料添加剂委員会

A 重油の低温流動性を測定しうる試験法を確立し， 流動性向上剂の評価法を検討するために，燃料フィル ター目詰り試験法（CFPP法）に和ける目詰り温度と JIS 法に括ける流動点とを比較する照合試験を行なっ た。その結果，次のような結論が得られた。

(1) CFPP 法を軽油拈よび A 重油に対する流動性 向上剂の評価をする試験法とする可能性はある。

(2) CFPP 法を正式の試験法にするためには，試 料油の低温流動性に影響を括よぼす因子や測定精度に ついて厳密に規定する必要がある。

（3）流動性向上剤の性能を比較する場合には, 試料 油の低温流動性をよくする最適の混入量が存在するの で，この点を考慮する必要がある。

\section{1. まえがき}

従来，わが国では重質油の低温流動性を測定する方 法として, 最低流動温度を計測する 流動点法 (JIS k2269) が規定されているが，寒冷地あるいは冬期に 和ける貯蔵または使用時などのよらに実用時の流れの 場に扣ける関連が不十分であるとされている。

そこで，当委員会では JIS 法の流動点試験の改良 法ともいえる低温度下での燃料フィルター目詰り試 験, CFPP (The Cold Filter Plugging Point of Distillate Fuels, IP 309/74 Tentative) に抢ける目 詰り温度と JIS 法の流動点とを比較すするとによっ て，A 重油の低温流動性を測定しうる試験法を検討 し，流動性向上剤の効果の判定に適用できるかどうか について，その第一歩として照合試験を些施し若干の 成果を得たのでここに報告する。

\section{2. 研究調查の経緯}

\section{1 委員会の構成}

当委員会の委員名和よび勤務先をまとめて表 1 に示 す。

表 1 燃料添加剤委員会委員

\begin{tabular}{|c|c|c|c|c|c|c|c|}
\hline & & & & 氏 & 勤 & 務 & 先 \\
\hline 委 & 員 & 長 & 内海 & & \multicolumn{3}{|c|}{ 東京商船大学 } \\
\hline 幹 & & 事 & ○重田 為良 & & \multicolumn{3}{|c|}{ 公害資源研究所 } \\
\hline & $\prime \prime$ & & ○柳沢堅太郎 & （昭和52年 6 月まで） & \multicolumn{3}{|c|}{ 日本油化工業(株) } \\
\hline & $\prime \prime$ & & ○渡辺 純 & （昭和52年 7 月より） & \multicolumn{3}{|c|}{ 山水商事(株) } \\
\hline & $\prime \prime$ & & ○岡田 & & \multicolumn{3}{|c|}{ 東京商船大学 } \\
\hline \multirow[t]{11}{*}{ 委 } & & 員 & ○古賀 雄造 & & \multicolumn{3}{|c|}{ 東亜燃料工業(株)中央研究所 } \\
\hline & $\prime \prime$ & & ○岡本登志夫 & （刏谷新吾, 小島征帆, 沖中敏夫, 松井敏博) & \multicolumn{3}{|c|}{ 出光興産(株) } \\
\hline & $\prime \prime$ & & ○富越 晧祐 & （本橋正道，嶋田普広） & \multicolumn{3}{|c|}{ 全漁連油質研究所 } \\
\hline & $\prime \prime$ & & 佐賀井 武 & & \multicolumn{3}{|l|}{ 群馬大学 } \\
\hline & $\prime \prime$ & & 東海林正樹 & （佐藤三倉） & \multicolumn{3}{|c|}{ タイホー工業(株) } \\
\hline & $\prime \prime$ & & 佐々木正俊 & （宮本賢造） & \multicolumn{3}{|c|}{ ネオス工業(株)(新日東化学(株)) } \\
\hline & $\prime \prime$ & & 上住 竜平 & & \multicolumn{3}{|c|}{ 丸和物産(株) } \\
\hline & $\prime \prime$ & & 坂田 靖彦 & （布施芳哉） & \multicolumn{3}{|c|}{ 日本添加剤工業(株) } \\
\hline & $\prime \prime$ & & 岩木 文男 & (松本滋) & \multicolumn{3}{|l|}{ 山水商事 } \\
\hline & $\prime \prime$ & & 祐邦 & & \multicolumn{3}{|c|}{ 国鉄技術研究所 } \\
\hline & $\prime \prime$ & & 奥田 将德( & (青木征二郎), 高松邦夫(昭和52年12月より) & \multirow{2}{*}{\multicolumn{3}{|c|}{$\begin{array}{l}\text { 日本郵船(株) 油炭効率研究所 } \\
\text { 成膎大学 }\end{array}$}} \\
\hline 顧 & & 問 & 安東 新午 & & & & \\
\hline
\end{tabular}

（○：幹事会委員） 
表 2 現在, 国内で入手可能な流動性向上剂の種類

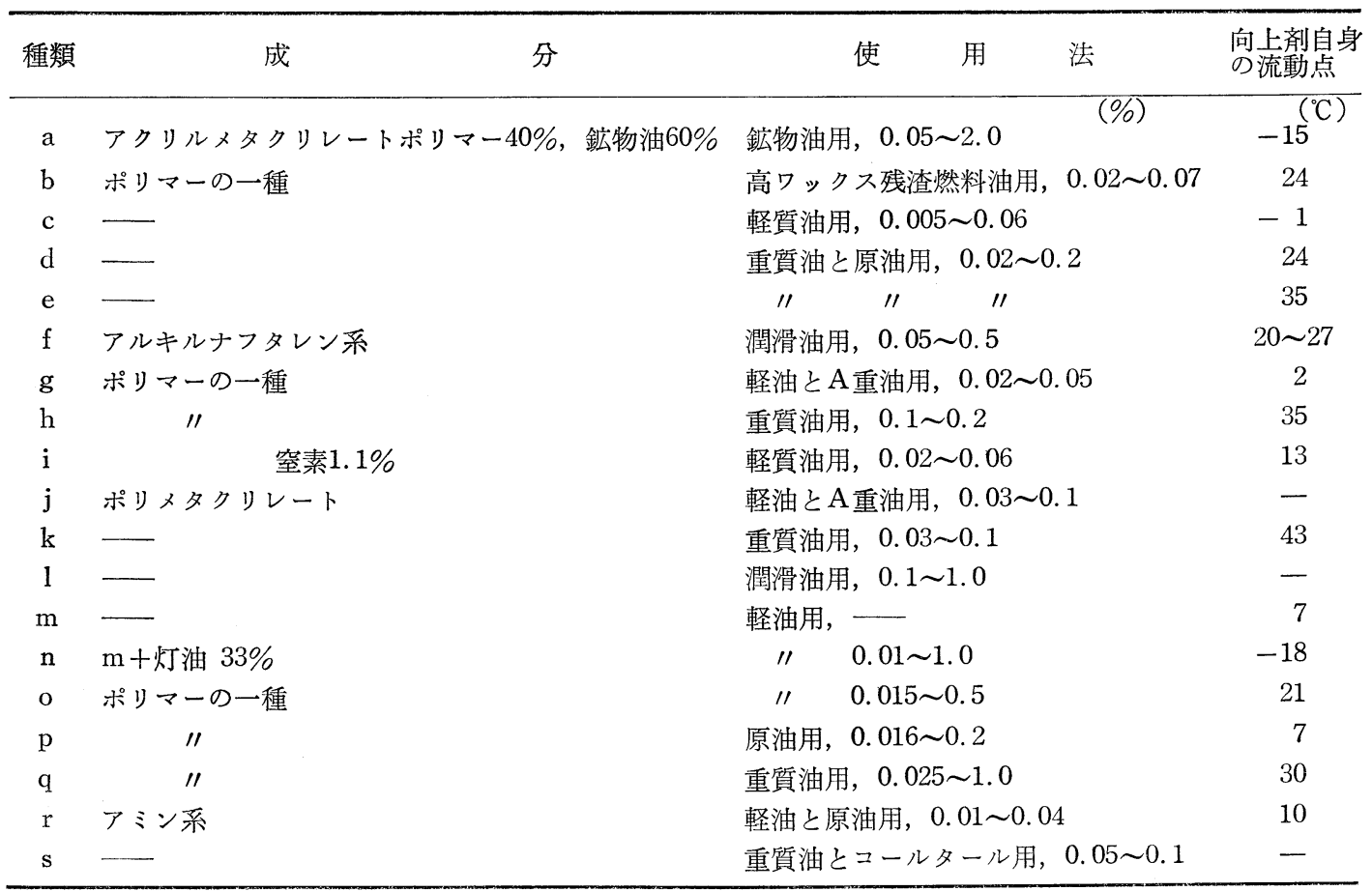

\section{2 経緯}

昭和50年 11 月から昭和53年 3 月までの間に，4回の 委員会と 6 回の幹事会を開き, CFPP 法に関する資 料括よび A 重油の低温特性の検討, 試料油および流 動性向上剂の選定, 2 回の照合試験の実施扣よびその 結果の検討などを行ない, ぬとめられたのが本報告で ある。

\section{3 流動性向上剂の現況}

今回の照合試験の実施に際し, 現在国内で入手でき る流動性向上剂の種類，成分および使用法などについ て調查した結果を表 2 に示す。

\section{4 試験場所}

照合試験の実施場所は公害資源研究所, 全漁連油質 研究所和よび東京商船大学の 3 か所である。試料油の 一般性状は公害資源研究所と出光興産(株)で分析し た。

\section{3. 試験}

\section{1 試験装置}

今回の試験に用いた装置はIP309/74 に準拠した目 詰り試験装置と JIS 法に 規定されている最低流動点 法の 2 つである。後者の装置および方法については省 略する。前者の装置の概略図を図 1 亿示す。試験装置 は図からも明らかなように, 試料油をフィルターする
部分，試料油を低温度に保つ部分和よび試料油を一定 吸引力で吸引する部分などから構成されている。フィ ルター部の詳細図を図 2 に示す。試料油は銅製のメッ シュフィルターを通って, 図のように内径 $4.0 \mathrm{~mm} \phi$ のガラス管内を流れて大気中に露出されているピペッ 卜内に溜るようになる。この量が $20 \mathrm{ml}$ 流れるのに， 初めて60秒以上になるときの試料油の温度を目詰り温 度と称し，試料油の低温流動性を示す測定項目であ る。つまり，目詰り温度が低い注ど，低温流動性がよ いことになる。

図 2 に示すように, 内径 $32 \mathrm{~mm} \phi$, 長さ $120 \mathrm{~mm}$ の ガラス製の試験管内に一定量 $(45 \mathrm{ml})$ の試料油を入 れ，その試験管は 3 本の断熱リングで内径 $44.5 \mathrm{~mm} \phi$, 深さ $113 \mathrm{~mm}$ の金属製ジャケット内に固定する。そ して，そのジャケットをエチルアルコールとドライア イスなどを使用した冷却浴内に入れ試料油を冷却す る。つまり，試料油は試験管を泠却液によって直接冷 却されるのでなく, 冷却液によってジャケットを冷却 し，熱伝達係数の小さい空気層を介して試験管を冷却 する構造になっている。この点が後述する試料油の冷 却速度に関係してくる。試料油は水柱 $200 \mathrm{~mm}$ に保 たれているタンク内に吸引されるよらに工夫されて いる。 


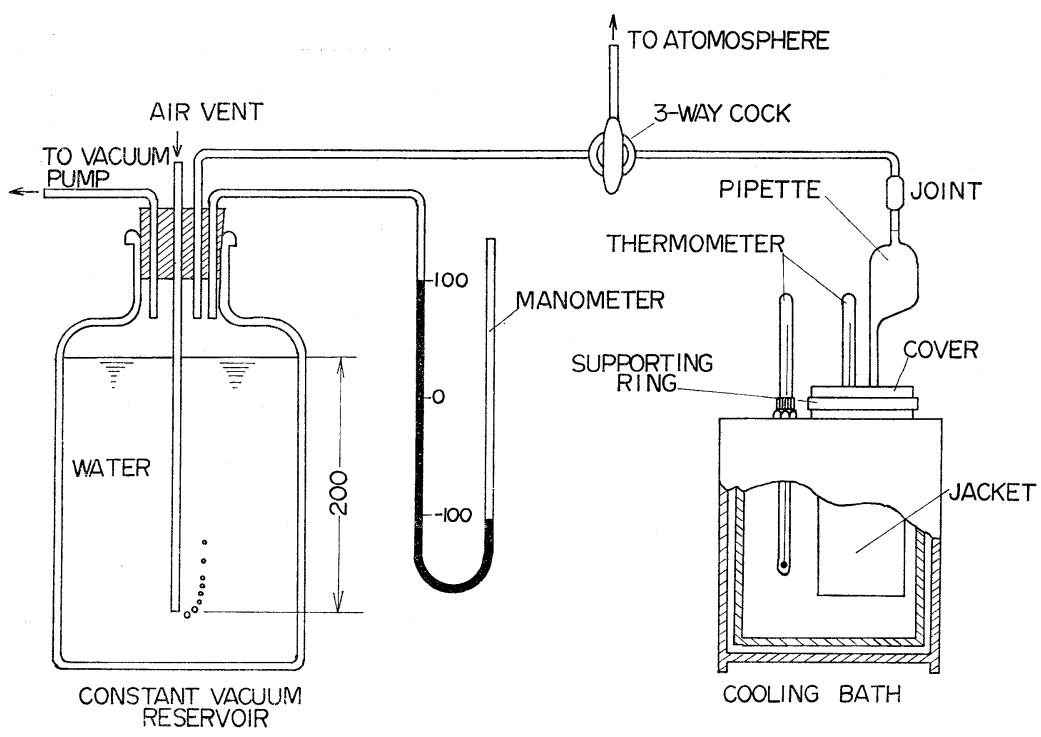

図 1 CFPP 法の試験装置

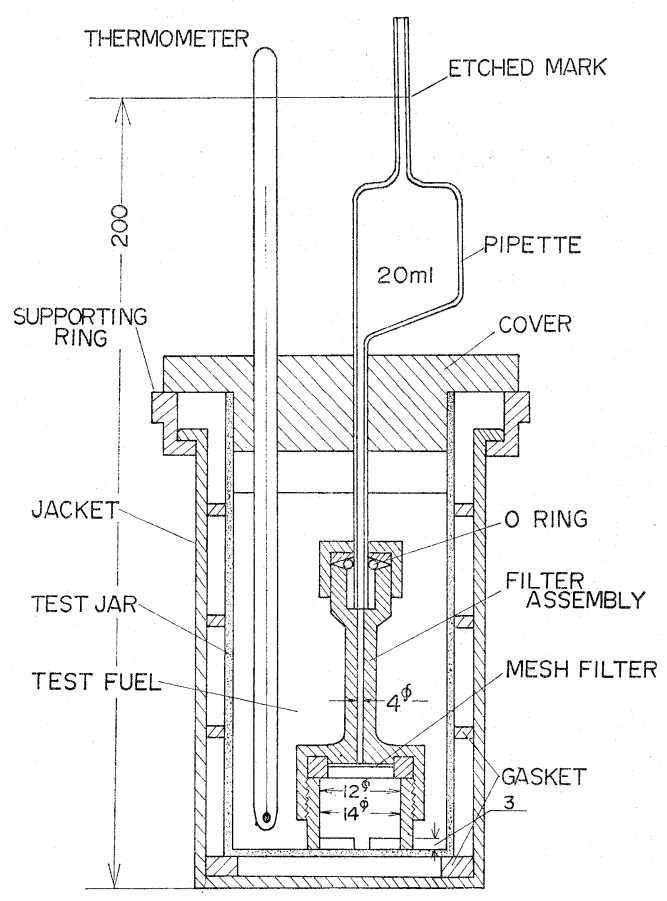

図 2 CFPP 法のフィルター部の野細図

\section{2 試験方法}

\section{2 .1 装置の準備}

JIS k8594 石油ベンジンの特級またはトリクロロ エタンをピペットの標線 $(20 \mathrm{ml})$ の上まで, 減圧を 用いて吸い上げて装置内部を清浄にする。吸上げ操作
を10回繰り返し行ない，ついで溶剤を取り替えて全操 作を繰り返す。次に空気を装置内に送って乾燥する。 金網のよごれまたは損傷を検査し，必要に応じて新し いものと交換する。試験に際しての標準の金網は 400 メッシュとする。

\section{2 .2 装置の操作}

(1) あらかじめ乾燥した外管の底に乾燥した環状ス ペーサを扣き，試料を試験管の標線 $(45 \mathrm{ml})$ まで入 れ, 試験管の外側をめぐって清浄乾燥する。沪過器付 ピペットと温度計を取り付けた試験管ぶたで試験管を 閉じる。予期沪過器目詰り温度が $-30^{\circ} \mathrm{C}$ 未満の試料 の場合は, 低流動点用温度計（JIS 7410 の温度計番 号10）を用いる。試験の途中で温度計をかえてはなら ない。

（2）試験管を外管内に垂直に取り付け，沪過器を試 験管の底面上に拈き，温度計をその下端が試験管の底 面上 $1.3 \sim 1.7 \mathrm{~mm}$ にくるよらに0リングを用いて固 定する。外管を冷却浴から取りはずしできる場合は, 試験管を取り付けた外管は $-34 \pm 0.5^{\circ} \mathrm{C}$ に保持した 冷却溶中の 83 $87 \mathrm{~mm}$ の深さに垂直に扣く。

(3) 真空用ゴム管でピペットの頂部の吸引装置へ接 続する。直ちに測定を開始できるが，試料の曇り点が わかって括れば，量り点より少なくとも $5{ }^{\circ} \mathrm{C}$ 高い温 度に試料が冷却されるまで，測定を持つのが望まし W。

（4）三万コックを回わして，沪過器付ピペット内を 減压に吸引開始し，金網を通してピペット内へ試料をを 
吸い上げる。試料がピペットの標線に達したら，三力 コックを元の位置に回わして，ピペット内へ空気を入 れ，試料を試験管へ戻す。

（5）吸引開始から試料が標線まで吸い上げられるの

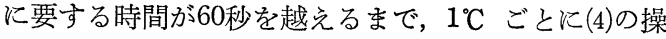
作を繰り返して沪過器目詰り温度を測定する。

(6) 試料の温度が $-22 \pm 2{ }^{\circ} \mathrm{C}$ になっても沪過器目 詰り温度が観測されない場合は，試験管を $-51 \pm 0.5$ ${ }^{\circ} \mathrm{C}$ に保持した冷却浴の外管内一速やかに移す。この ようにして試料温度が $-35 \pm 2{ }^{\circ} \mathrm{C}$ になっても, 沪過 器目詰り温度が得られない場合は，測定を中止し，洰 過器目詰り温度を $-35^{\circ} \mathrm{C}$ 以下と判定し報告する。

\section{3 第 1 回試験}

試験に用いた試料油はパラフィン系基油の軽油 3 種 類と JIS 流動点が $-7 \sim-8^{\circ} \mathrm{C}$ 付近と $-15 \sim-20^{\circ} \mathrm{C}$ 付近の A 重油 2 種類とした。その一般性状を表 3 に 示す。をた流動性向上剤は表 2 のなかからできるだけ 成分の明らかな 5 種類を用いた。試験に際しては, 試 料油の熱経歴を統一するために, 試料油を約 $50^{\circ} \mathrm{C}$ で 1 時間加熱後に 流動性向上剂を外割混合（重量 \%)

で規定量だけ加えて十分に攪汼するよらにした。

試験結果を CFPP 法と JIS 法とを比較して表4

\section{表 3 試料油の一般性状}

\begin{tabular}{|c|c|c|c|c|c|}
\hline $\begin{array}{ll}\text { Items } & \text { Fuels } \\
\end{array}$ & Gas Oil (A) & Gas Oil (B) & Gas Oil (C) & Diesel Oil & Diesel Oil \\
\hline Specific Gravity, $15 / 4^{\circ} \mathrm{C}$ & 0.837 & 0.830 & 0.821 & 0.840 & 0.83 \\
\hline Flash Point, ${ }^{\circ} \mathrm{C}$ & 79 & 69 & 71 & 93 & 74 \\
\hline Kinematic Viscosity, $50^{\circ} \mathrm{cSt}$ & 325 & 3.30 & 3.20 & 2.77 & 2.52 \\
\hline Initial Boiling Point, ${ }^{\circ} \mathrm{C}$ & 190 & 197 & 180 & 207 & 185 \\
\hline $10 \%$ Evaporated Point, ${ }^{\circ} \mathrm{C}$ & 220 & 234 & 233 & 236 & 239 \\
\hline $50 \%$ & 267 & 269 & 267 & 276 & 276 \\
\hline $97 \%$ & 330 & 323 & 310 & 363 & 340 \\
\hline End Point, ${ }^{\circ} \mathrm{C}$ & 337 & 331 & 315 & 373 & 346 \\
\hline Caiculated Cetane Index & 55.5 & 55.9 & 55.9 & 55.1 & 55.1 \\
\hline Wax, wt\% & $<0.1$ & $<0.1$ & $<0.1$ & 0.6 & $<0.1$ \\
\hline Cloud Point, ${ }^{\circ} \mathrm{C}$ & -7 & -4 & 7 & - & \\
\hline Pour Point, ${ }^{\circ} \mathrm{C}$ & -17.5 & -15.0 & -10.0 & -7.5 & -15.0 \\
\hline
\end{tabular}

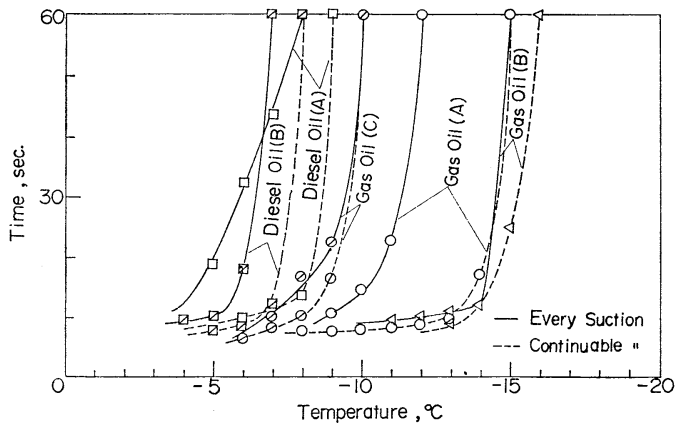

図 4 試料油の吸引状態の違いと流動特性との 関係

に示す。また, 現行の CFPP 法の試験装置和よび寒 施要領が軽油について規定したものであるから A 重 油にその規定を適用できるかどらかを調べる必要があ る。図 3 にフィルターメッシュの大ささと流動特性と の関係, 図 4 に試料油の吸引状態の違いと流動特性と の関係をそれぞれ示した。また，流動性向上剂の混入 量と流動特性との関係を困 5 に示した。これらの3つ の図に扣いて，縦軸の60秒に相当する温

表 4 CFPP 法と JIS 法との試験結果の比較（第 1 回試験）

CFPP : The Cold Filter Plugging Point of Distillate Fuels (IP 309/74 Tentative)

JIS : Testing Method for Pour Point of Petroleum Products (JIS k2269/74)

\begin{tabular}{|c|c|c|c|c|c|c|c|c|c|}
\hline & Gas & ISA) & & Gas Oill(B) & Gas oillc) & Diesel 0 & $i(A)$ & Diesel o & il (B) \\
\hline & $x$ & $Y$ & $z$ & $Y$ & $Y$ & $x$ & $Y$ & $Y . \ldots$ & $z$ \\
\hline & F..J & FPR.」IS: & CEPP & CFPP JIS & CEPP JIS & CEPR JIS & CEPR.JI & CFPPUJIS & CFPP \\
\hline Ian & $-15.0-20.0$ & $-14.0-17.5$ & -120 & $-16.0-15.0$ & 100 & $-10,0-10.0$ & $-9.0-100$ & $-11.0-15.0$ & -7.0 \\
\hline a & $-150-$ & $-21.0-30.0$ & -16.0 & $-19.0-20.0$ & $-13.0-15.0$ & $-13.0-$ & $=11.0-20$ & 17.5 & -13.0 \\
\hline c & $-24.0-$ & $-230-300:$ & -17.0 & $-16.0-17.5$ & $-11.0-10.0$ & $-10.0-$ & $-8.0-10.0$ & $-15.0-17.5$ & - \\
\hline d & -- & $-17.0-35.0$ & - & $-15.0-17.0$ & $-11.0-7.5$ & $-13.0-$ & $-8.0-5.0$ & -13 & 11.0 \\
\hline j & $-19.0-$ & $-20.0-2$ & - & $-20.0-20.0$ & $13.0-12.5$ & $-23.0-$ & $-15.0-22$ & -15.0 & -12.0 \\
\hline 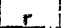 & $1-210-1$ & $-20.0-35$ & 6.0 & $7.0-25.0$ & $-13.0-12.5$ & $-13.0-$ & & & 13. 6. \\
\hline
\end{tabular}

度が目詰り温度になる。

これらの試験結果から次のことが明ら かになった。

（1）表 4 に示すように，各試験場所に おける測定值は多少ばらついているが， 全体としていずれの流動性向上剤る流動 性を良くする効果があり, 現行 JJS 法 でも CFPP 法でも測定できる。

(2) 試料油の種類により流動性向上剂 の効果に相違がある。

(3) フィルターメッシュの大きさは A 重油の場合，目詰り温度に大きな影響を 


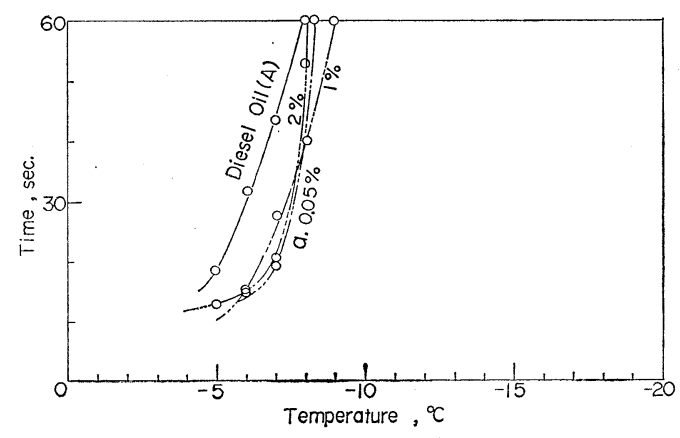

図 5 流動性向上剂の混入量と流動特性との関係

光, 軽油の場合は, その影響は少ない。

(4) 試料油の吸引状態の違い, つ主，同一試料油 を繰り返して連続吸引した場合と一回吸引する毎に試 料を入れ替えて用いた場合とを比較すると，軽油と $\mathrm{A}$

\section{表 5 殘さ油の一般性状}

\begin{tabular}{|l|r|}
\hline Specific Gravity, 15/4c & 0.9536 \\
Flash Point, ${ }^{\circ} \mathrm{C}$ & 172 \\
Kinematic Viscosity, 50 cSt & 168 \\
Pour Point, ${ }^{\circ} \mathrm{C}$ & 0 \\
Sulfur, wt \% & 3.15 \\
Carbon Residue ,wt\% & 843 \\
Water, wt \% & Trace \\
Ash, wt \% & 0.04 \\
Metals, ppm & \\
$\mathrm{V}$ & 38 \\
$\mathrm{Ni}$ & 10 \\
$\mathrm{Fe}$ & 6 \\
$\mathrm{Na}$ & 130 \\
\hline
\end{tabular}

表 6 CFPP 法と JIS 法との試験結果の比較 (第 2 回試験)

CFPP : The Cold Filter Plugging Point of Distillate Fuels (IP 309/74 Tentative)

JIS : Testing Method for Pour Point of Petroleum Products (JIS k 2269/74)

\begin{tabular}{|c|c|c|c|c|c|c|c|c|}
\hline & & & Places & \multicolumn{2}{|c|}{$x$} & \multicolumn{2}{|c|}{ Y } & \multirow{2}{*}{$\begin{array}{c}z \\
\text { CFPP }\end{array}$} \\
\hline & \multicolumn{2}{|c|}{ Fuels } & Methods & CFPP & JIS & CFPP & JIS & \\
\hline \multicolumn{4}{|c|}{ Gas Oil (A) } & -15.0 & -20.0 & - & - & - \\
\hline \multicolumn{4}{|c|}{ Gos Oil $(A)+$ Bottom Oil.1\% } & -18.0 & -25.0 & -19.0 & -25.0 & -14.0 \\
\hline " & + & $"$ & $+C .1 \%$ & -18.0 & -30.0 & -19.0 & -30.0 & -16.0 \\
\hline$"$ & + & $"$ & $+j .1 \%$ & -20.0 & -27.5 & -20.0 & -25.0 & -16.0 \\
\hline$"$ & + & $"$ & $+r .1 \%$ & -21.0 & $<-35.0$ & -21.0 & $<-350$ & -16.3 \\
\hline \multicolumn{4}{|c|}{ + Bottom Oil.3\% } & -21.0 & $<-35.0$ & -22.0 & $<35.0$ & -17.0 \\
\hline$"$ & + & $"$ & + C. $1 \%$ & - & 一 & - & 一. & -13.0 \\
\hline$"$ & + & " & + c. $0.2 \%$ & -22.0 & $<-35.0$ & -21.0 & $<-35.0$ & -16.0 \\
\hline$"$ & + & $"$ & $+j .1 \%$ & - & - & - & - & -20.0 \\
\hline$"$ & $t$ & $"$ & $+j .0 .2 \%$ & -25.0 & -35.0 & -26.0 & $<-35.0$ & -22.0 \\
\hline " & + & $"$ & $+r .1 \%$ & - & - & - & - & -17.0 \\
\hline$\|$ & \pm & $n$ & tr. $0.2 \%$ & -27.0 & -35.0 & -27.0 & -35. & -21.0 \\
\hline
\end{tabular}

重油とも前者が後者より流動性がよくなる結果が表わ れる。

（5）今回の試験で混入した流動性向上剂の混入量の 範囲では混入量の少ない場合が多い場合より流動性が よくなる結果が得られた。最適混入量などについてる ら少し検討を加光る必要がある。

\section{4 第 2 回試験}

試料油として，軽油（A) そイラニアン・ヘビーの 残さ油を加光たものを選定した。流動性向上剂は第 1 回試験之同一のものを重量％で混入して用いた。残 さ油の一般性状を表 5 亿示す。その試駼結果をCFPP 法と JIS 法と比較して表 6 亿示す。この結果から次 の点が明らかになった。

(1) CFPP 法による測定值にばらつきがみられる のは試料油の冷却速度を明確に規定しなかったことに 原因の一つがあると考光られる。JIS 法による測定值 はほとんどばらつきがなくよい結果が得られた。

（2）（1)の冷却速度とも関連して, 測定值の精度を上 げるためには CFPP 法の装置のコックの開閉などを 自動化する必要がある。

（3）表 4 と表 6 とより，軽油に今回用いた残さ油を 加光ると試料油の流動性が軽油よりよくなる結果が得 られた。この試料油が A 重油に相当すると考光ると， 複雑な組成のものに流動性向上剤を混入したときの挙 動は相当飞難解なるのであろらことが予湘される。

\section{4. 結 論}

以上の 2 つ試験結果をまとめると次のようにな る。

(1) CFPP 法を軽油拈よび A 重油に対する流動 性向上剂の評価をする試験法とする可能性はある。

（2）正式の試験法にするためには，試料油の流動性 に影響を特よぼす因子*や測定精度について厳密に 規 定する必要がある。また，測定操作の自動化について る検討する必要がある。

（3）流動性向上剂は流動性を良くする最適の混入量 が存在するので，その性能を比較する場合は，この点 を考慮する必要がある。

$$
\text { 文献 }
$$

1) R. Greatorex, J.Institute of Petroleum, 49, 259 (1963)

*R. Greatorex ${ }^{1}$ がすでに CFPP 法を B 重油飞適 用した試験結果から指摘しているのと同じように， $\mathrm{A}$ 重油についても最適メッシュの大きさ, 試料油 の冷却速度および吸引速度などについても十分に検 討する必要がある。 
試料油括よび流動性向上剂の協力会社名

今回の照合試験に際し，下記の各会社から試料油抒

よび流動性向上剤の提供の協力を得たので，ここに報

告し感謝の意を表わす。

出光興産株式会社
シェル化学工業株式会社

日揮ユニバーサル株式会社

エッソ化学工業株式会社

日本ケミカル工業株式会社

\title{
Investigations on the Estimation for Flow Improvers
}

\author{
by Fuel Oil Additive Committee, The Fuel Society of Japan
}

SYNOPSIS:-As a first step to study the low temperature flow properties of some residual fuels and to investigate the measurement of the efficacy by flow improvers, a comparative test was conducted with two methods of the CFPP and the JIS.

From some experimental results, the following conclusions were obtained.

(1) It is possible to estimate the CEPP as a testing method for gas oil and diesel oil mixed with flow improvers.

(2) In order to establish the CEPP as a formal testing method, many very strict restrictions must be obeyed for the accuracy of the measurement and some factors that affect to the low temperature flow properties of fuels.

(3) As the flow improvers have the optimum mixing weight for improving the low temperature flow properties respectively, in case of comparing the efficacies by them, it must be considered that. 